\title{
AN ANALYSIS OF ENGLISH TEACHERS' SPEAKING SKILL AT THE COASTAL SCHOOLS IN BENGKULU CITY
}

\author{
Ildi Kurniawan \\ Universitas Bengkulu \\ ildikurniawan@unib.ac.id \\ Syafrizal Sabaruddin \\ Universitas Bengkulu \\ syafrizal_sabaruddin@yahoo.com
}

\begin{abstract}
This study aims to illustrate the speaking skills of English teachers on the coastal school of Bengkulu City as well as the factors that influence the speaking skills. This research was a descriptive-qualitative research which was also a continuation of previous research on students' speaking skills in the coastal area. The subjects of this study were English teachers who attended school, namely English teachers at SMAN 6 Kota Bengkulu, SMAN I Kota Bengkulu and SMAN 7 Plus Kota Bengkulu, SMPN 7 Kota Bengkulu, SMPN 1 Kota Bengkulu, SMPIT Iqra 'Kota Bengkulu, SMPN 15 Kota Bengkulu. Data that has been obtained in the form of audio-visual recordings when the teacher spoke English, as well as an interview recording related to the speaking skills of the English teacher. The data obtained were analyzed, interpreted and concluded as findings by using the Interactive Model technique namely reduction, display, drawing a conclusion. The results of this study indicated that the English teachers' speaking skills at the Bengkulu City coastal school was at a moderate level. Fluency in speaking was the main problem faced by these teachers. In addition, grammar also became an obstacle for them. While the identified factors that couldinfluence the English teacher's speaking skills were the internal factors of English teachers themselves who often used Indonesian language when teaching rather than English itself with the reason that children would easily understand the message or subject matter when compared to English. In addition, curriculum change as an external factor was also a reason for English teachers not to speak English much in class with the latest curriculum consideration, namely the 2013 Curriculum requires active students, not teachers
\end{abstract}

Keywords: Analysis, Skills, Speaking, English, Coastal

\section{INTRODUCTION}

English is a foreign language in the Indonesian education curriculum. Therefore, as a foreign language, English is important to be taught to students so that they can master English well and correctly and finally they are able to compete at the local, national and even international level through their language competencies.

Because this speaking skill is difficult (Kamil, 2017), the teacher's factor as a role model or language input for students is very important in determining the success of students in English. This is caused by teachers who most often interact with students when learning English. What the teacher teaches will be followed and imitated by his students. Therefore, in accordance with Law Number 14 of 2005 concerning Teachers and Lecturers which is reinforced by the Minister of National Education Regulation No. 16 of 2007, the requirements of foreign language teachers, especially English, they must have four competencies namely pedagogic competence, professional competence, personality competence and social competence. 
Especially for professional competence, teachers are required to be able to master English both oral and written. But in reality, although as many as $71.1 \%$ of English teachers in the city of Bengkulu already have certification of educators (Damayanti, 2014), there are still many students (especially in the city of Bengkulu) who cannot speak English well and correctly especially speaking skills (Kurniawan, et al. 2016) although the teacher is considered quite professional (Damayanti et al. 2014). Meanwhile, the need for qualified teachers is needed in developing English language education as a foreign language in Indonesia (Kamil, 2017)

Therefore, this study tries to investigate whether the teacher's English language skills, especially speaking, have to do with the results of previous studies conducted by Kurniawan, et al (2016) regarding students' language speaking skills in the Bengkulu City coastal school. This research is different from previous studies because there has been no research describing the speaking skills of English teachers, especially in the coastal schools of Bengkulu city. Meanwhile, the potential of the city of Bengkulu's coastal schools is large enough to create students who are fluent in English in the future because of the average ability to speak English students in coastal schools are included in the medium level (Kurniawan et al. 2016). Of course, to raise the level of speaking skills, another important thing to note is the English teacher. In addition, the existing research so far has only focused on the teacher's profile, not touching the English teacher's speaking skills

Based on the background of the above problems, the formulation of the problem in this study can be formulated as follows: How is the English teacher speaking skill in the Bengkulu City coastal school? What factors influence the English teacher's speaking skills of students in the Bengkulu City coastal school? Whereas based on the formulation of the research above, this study aims to: Provide an overview of the English teacher's speaking skills in the Bengkulu City coastal school area. Provide an overview of the factors that influence the language teacher's speaking skills in the Bengkulu City coastal school.

The benefits of this research can be viewed from a theoretical and practical perspective. In terms of theory, it is hoped that the results of this study can contribute to the development of the typical sciences, especially English specifically in the field of speaking skills. In practical terms, it is expected that the results of this study can be a reference for the Bengkulu City Education and Culture Office in obtaining policies related to the empowerment of coastal schools in the field of education. For teachers, it is hoped that the results of this study will be the main reference as well as a discussion of studies in English teaching and learning activities in the classroom. Furthermore, the results of this study are also expected to provide benefits for students in the coastal city of Bengkulu, namely as information and motivation material when they learn English.

\section{LITERATURE REVIEW}

Speaking skills are one of the skills in English. This speaking skill becomes dominant for a person, especially the teacher because through speaking, a teacher can express feelings, ideas, ideas, knowledge, and other important information to students.

These skills are oral skills that can be directly heard and imitated by students when they interact in the learning process in the classroom. Therefore, teachers must have these skills well because they will become role models for their students. Errors in pronunciation, for example, will affect the possibility of the same mistakes in children. Because of the risks that might result from this error in speaking, many teachers and students acknowledge that this speaking skill is one of the difficult and complex skills to be mastered (Kamil, 2017). 
There are a number of English speaking skills that teachers and students must master, namely micro-skills and macro-skills from speech (Brown, 2009) namely. Micro skills are the smallest skills of the language, namely mastering English phonemes, morphemes, words, collocations and unit phrases, while macro-skills include the ability of the speaker to speak fluently, understand discourse, understand language functions, and have language styles (style), cohesion, mastering nonverbal communication, using language learning strategy.

In addition, there are several classroom activities that teachers can use to teach these speaking skills, for example, role play, discussions, interviews, presentations. However, the teacher must choose these activities according to the students' abilities and their interest in learning English (Kurniawan, 2015).

\section{The Role of Teachers in Learning English}

From the main function of speaking skills, we can take several roles from an English teacher, especially in class. Based on the function of the speaking skills offered by Richard (1996), it can be concluded that several important roles of a teacher in English classes. First, speaking as an interaction (talking as interaction), speaking as an interaction means that the conversation is done as a form of social interaction with people around, for example when a person gives greetings. The characteristics of this conversation are more family-friendly, the situation is formal and informal. this means that the teacher must have good English skills so that he is able to interact with students or students in class. You can imagine how the form of interaction if the teacher does not have the qualifications to speak good English in class Second, speaking as a transaction (talks as transaction). Talking as a transaction means that the conversation that is done with the focus of the delivery is the message. Because in the conversation the English teacher must have several skills related to the ability to ask, clarify, confirm, give advice and others.

Furthermore, speaking as performance (talks as performance) means talking as a skill as a performance or display of purpose is a public conversation such as giving a speech, greeting, giving announcements and so on. To be able to do the task or role, the English teacher must have qualified English language skills.

The three functions of speaking skills are related to each other and are very important to be taught to students so that they can adjust their speaking skills according to the right context.

In addition to the above roles the following teachers are some other roles of an English teacher, one of which is as a holder of control over the content of the material needed by students and controlling the implementation of teaching and learning activities in the classroom (Nation and Newton, 2009). Furthermore, the role of the teacher is also as a facilitator and as a source of information for students (Voller, 1997) and as the implementer of learning strategies for students (Talley and Ling, 2014).

Tabel 1. English Teacher's Profile in Bengkulu City

\begin{tabular}{llll}
\hline Jenis Profil & Rincian & Jumlah & Pesentase \\
\hline Jenis Kelamin & Laki-Laki & 13 & 28.9 \\
& Perempuan & 32 & 71.1 \\
\hline
\end{tabular}




\begin{tabular}{llll}
\hline $\begin{array}{l}\text { Pendidikan } \\
\text { Terakhir }\end{array}$ & S1 & 42 & 93.3 \\
Masa Kerja & 5-10 tahun (terendah) & 3 & 6.7 \\
& 20 Tahun ( tertinggi) & 11 & 26.7 \\
Sertifikasi & Bersertifikat & 32 & 71.1 \\
& Tidak bersertifikat & 12 & 26.7 \\
Pemakalah & Ya & 6 & 13.3 \\
Seminar & Tidak & 39 & 86.7 \\
Pelatihan & $1-3$ Kali & 27 & 91.1 \\
Bahasa Inggris & 10-15 kali & 1 & 2.2 \\
\hline Penghargaan & Ya & 4 & 8.9 \\
\hline
\end{tabular}

From the profile data of English teachers in the city, it can illustrate several things. First, English teachers are more dominated by women (32 people) while in terms of education it is found that there are no longer teachers who graduated from Diploma or High School. In terms of qualification it is stated that almost all English teachers on the coast of Bengkulu city are certified (71.1\%). But unfortunately, even though the teacher has worked for more than 5 years, in terms of personal competence, especially in terms of awards, self-development through training and attending seminars both nationally and internationally is still low.

From the profile also, Damayanti (2014) later said that the competence of English teachers in the city of Bengkulu was still in the category enough. He also suggested that further research be carried out to improve teacher competencies, especially pedagogic, social and professional competencies.

Underlining these suggestions, this study sought to continue what was suggested, namely to find out the professionalism level of English teachers in speaking English in the coastal areas of Bengkulu city.

Next, observing from the data, the English teacher is predicted to have the ability to speak good English because almost all English teachers in the city of Bengkulu already have an educator certificate which means that they are professionally recognized

\section{RESEARCH METHODS}

This research is a qualitative descriptive study. This qualitative method is intended to understand social situations in depth to find patterns, hypotheses and theories. Therefore the purpose of the study was to answer the question of how to map English speaking skills of students in the coastal areas of Bengkulu City and what factors influence the students' speaking skills. 
The research site was all schools in the coastal area of Bengkulu city which consisted of SMAN 6 Kota Bengkulu, SMAN I Kota Bengkulu and SMAN 7 Plus Kota Bengkulu, SMPN 1 Kota Bengkulu, SMPIT Iqra 'Kota Bengkulu, SMPN 15 Kota Bengkulu.

The instrument of this study was a speaking test, in which the English teacher recorded his talk through a tape recorder or video camera when they taught English in class. Talking material was adjusted to the material that would be taught by the English teacher. The results of the recording were then grouped according to the level of school and the origin of the school where the English teacher teaches and then transcribes.

The sample of this study were English teachers in several schools on the coast of Bengkulu city, namely English teachers at SMAN 6 Kota Bengkulu, SMAN I Kota Bengkulu and SMAN 7 Plus Kota Bengkulu, SMPN 1 Kota Bengkulu, SMPIT Iqra 'Kota Bengkulu, SMPN 15 Kota Bengkulu. The sample data sources were selected by purposive sample technique and snowball sampling technique. In this Purposive sample technique the researcher chose an English teacher at the school who is considered to be giving the required data so that the number couldn't be determined while the snowball sample technique was used to find satisfactory data if the data previously obtained was incomplete.

In this study, data collection techniques were carried out through recording techniques and interviews. Selected English teachers were recorded and recorded when they spoke English with students in the classroom. The data was then transcribed to get an overview, pattern, or speaking style of the English teacher according to the English language proficiency assessment guidelines adapted from Brown (2009) which included the components of grammar, vocabulary, pronunciation, understanding/comprehension and fluency. While the interview was used to obtain information related to factors that influence their speaking ability. In this study, data analysis techniques used were data analysis using Interactive Models (Miles and Huberman, 1984), which included, firstly, Data Reduction. At this stage the data reduction research was summarizing the data obtained, choosing the main things about the data, focusing on the important data, looking for the themes and patterns of data obtained. In the process, the researchers also discussed with experts to discuss data that had findings. Secondly, Data Display. After the data is reduced, the researcher displays the data in the form of brief descriptions, charts, tables and relationships between categories so that it was easy to understand. Thirdly, Conclusion Drawing / verification. The final step was that the researcher made conclusions and verification in the form of new findings describing the results of the study.

\section{RESULTS AND DISCUSSION}

\section{A. Speaking skills of English Language Teachers at the Kota Bengkulu Coastal Coast School}

From the results of the analysis of existing research data, there are several findings that can be presented here: First, the speaking skills of English and junior high school teachers are generally at a moderate level. The details regarding their ability based on sub-skill from speaking skills can be described as follows:

Teachers

Graph 1. Results of the Speaking Skills of Middle School / Middle School English 


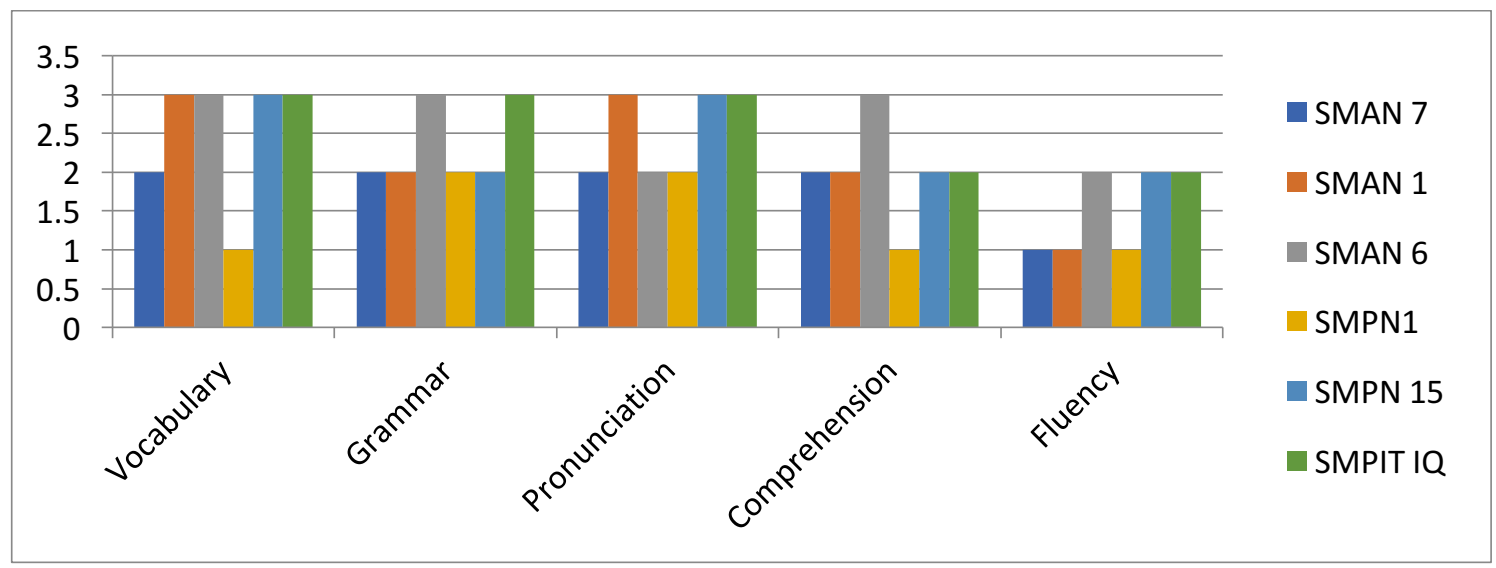

1: Poor

2: Moderate

3. Very Good

In general, the ability to speak English at the Bengkulu coastal school is at a moderate level. Compared to other subscriptions in this speaking ability, vocabulary (Vocabulary), Pronunciation (Pronunciation), which is owned by English teachers dominates compared to grammar, understanding (Understanding) and fluency.

Graph 2. English Language Teacher's Speaking Skills per School

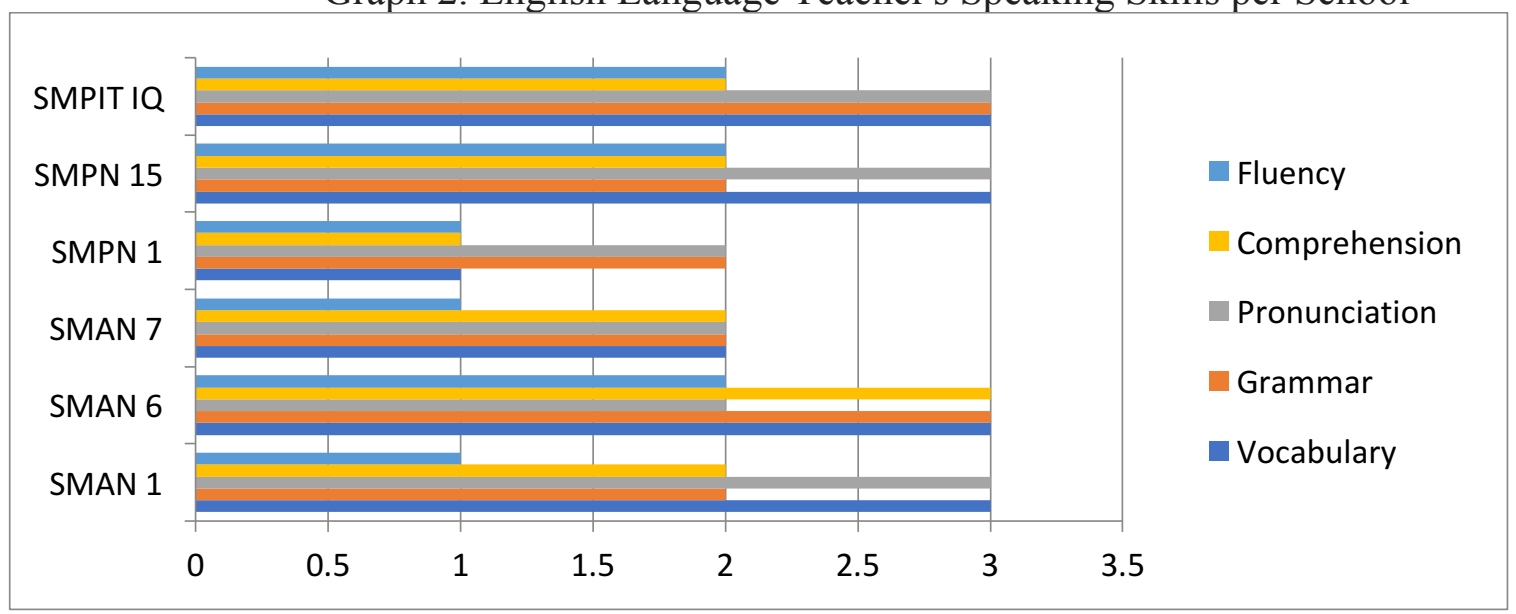

Judging from the English teacher's speaking skills in the Bengkulu coastal school, it is clear that the language of the English teacher from SMPIT Iqra 'and SMAN 6 can be categorized as having better speaking skills compared to other schools. In contrast, English language teachers from SMPN 1 have more obstacles in speaking English, followed by high school English teachersSMAN 7 who almost have the same problem when speaking English, fluency

Table 2. Summary of Problems Faced by English Teachers at Coastal Schools of Bengkulu City

No Problems




\begin{tabular}{|c|c|c|c|c|}
\hline Vocabulary & Grammar & Pronunciation & Compre & Fluency \\
\hline $\begin{array}{l}\text { Jarang } \\
\text { menggunakan } \\
\text { low frequency } \\
\text { words: Kata } \\
\text { yang digunakan } \\
\text { merupakan kata } \\
\text { yang sering } \\
\text { dipakai (High } \\
\text { frequency } \\
\text { words) } \\
\text { Misalnya: } \\
\text { happen } \rightarrow \text { take a } \\
\text { place } \\
\text { Discuss } \rightarrow \text { go } \\
\text { over,dan lainnya }\end{array}$ & $\begin{array}{l}\text { - Plural } \\
\text { form } \\
\text { (s/es) } \\
\text { e.g: How } \\
\text { many } \\
\text { persons } \\
\text { - Subject- } \\
\text { verb } \\
\text { agreeme } \\
\text { nt } \\
\text { e.g: Are } \\
\text { you } \\
\text { understa } \\
\text { nd? } \\
\text { What } \\
\text { does it } \\
\text { tells } \\
\text { you? } \\
\text { Prepositi } \\
\text { on, } \\
\text { to } \\
\text { infintive } \\
\text { e.g: I } \\
\text { want you } \\
\text { (to) } \\
\text { observe } \\
\text { Modal } \\
\text { perfect } \\
\text { e.g: Andi } \\
\text { Should } \\
\text { have } \\
\text { finished } \\
\text { wash his } \\
\text { car at } \\
\text { 08.00 }\end{array}$ & $\begin{array}{l}\text {-Stress } \\
\text {-Unclear voice } \\
\text {-Wrong } \\
\text { pronunciation: } \\
\text { student, } \\
\text { question) }\end{array}$ & $\begin{array}{l}\text { Mostly } \\
\text { the } \\
\text { respons } \\
\text { e (s) in } \\
\text { Indones } \\
\text { ia }\end{array}$ & $\begin{array}{l}\text { Too } \\
\text { much } \\
\text { fillers: } \\
\text { ah, I } \\
\text { think, } \\
\text { well }\end{array}$ \\
\hline
\end{tabular}

Factors that influence the Speaking Skills of English Teachers at Bengkulu City Coastal School

From the results of interviews and direct observation in the field, it can be concluded that there are several factors causing English teacher's speaking skills in the Bengkulu City coastal school:

\section{Internal Factor}

Of the six English teachers, all agreed to say that speaking skills for an English teacher were important. However, especially fluency language skills are skills that are difficult to master because they rarely practice speaking in English inside or outside the classroom. This is 
because when they speak English as a whole in class or outside the classroom, students cannot capture messages that are conveyed properly. Finally, situations like this make English teachers have to speak two languages at once namely English and Indonesian when they teach or interact with students. The factor "often relent" in the sense of rarely speaking English in its entirety is what then causes the fluency of speaking English teachers to be disturbed. It can be concluded that teachers feel their fluency in speaking English is caused by their frequent use of Indonesian rather than English when communicating both in the classroom and outside the classroom with the consideration that fear of the child does not understand the purpose conveyed when the teacher must speak fully in English.

\section{Curriculum Factor}

Curriculum changes from KTSP curriculum to the 2013 curriculum turned out to influence the perception of English teachers on the role of teachers in the classroom. In the 2013 curriculum, the approach used in the learning process is the scientific approach (scientific approach), namely the standard process in learning consists of Observing, Asking, Processing, Presenting, Summing up, and Creating. In this approach students seek knowledge rather than receive knowledge. Whereas in the KTSP curriculum, the approach used is the process skills approach where the process standard in learning consists of exploration, elaboration, and confirmation. Actually, the two curricula focus on student-centered learning. However, because the learning process relies on the student, which then causes the teacher to have reason to be passive when in class. This situation certainly makes the teacher speak a little unless needed. This will also affect the intensity of teacher speaking skills in English in class.

\section{DISCUSSION}

This section discussed the results of English teachers' speaking skills based on components / subscriptions of speaking skills: Vocabulary, Grammar, Pronunciation, Comprehension, and Fluency as well as factors that influence the English teacher's speaking skills.

\section{A. Subskills in speaking skill \\ Fluency}

The fluency of someone when speaking English can be seen from the quality and quantity of speech or speech that is issued from the mouth of a speaker. Someone who is said to be fluent in quantity is when he speaks in a certain tempo, then the amount of production of the word he produces is too much. However, it does not mean that a certain amount of words produced will guarantee the quality of someone's speaking. Therefore, a good language speaker must also pay attention to the quality of speech delivered so that it is easily understood by listeners or the other person.

In general it is very clear that fluency is the biggest challenge faced by English teachers, especially in the coastal school of Bengkulu city. But from the research findings above, there are several possible reasons why the fluency is difficult for English teachers to master - even though the results of the study indicate that the components of pronunciation are not all problems, but it is generally found that foreigners learning English will experience what is called a slip tongue - first, English is a foreign language whose pronunciation is different from their mother tongue. Secondly, such incompetence can also be caused by complicated and complex rules of English grammar so that teachers find it difficult to speak without thinking about the correct grammatical form. In fact, to be fluent in speaking English, teachers, including other language learners, are advised not to think about the grammatical form used when speaking because it will interfere with the fluency in speaking English. 


\section{Grammar}

Grammar is a rule of language use that must be mastered by a language learner, including learning English. In English, mastery of this grammar will lead a person to the correct use of tenses according to time (present, past, future).From the results of the research above, grammar is part of the sub-group which is difficult for the teacher to master when speaking. This can be seen from the table summarizing the difficulties faced by teachers regarding the use of good and correct grammar. The following are examples of common problems faced by English teachers on the coast of Bengkulu city related to the use of grammar.

1) Plural form (s / es), e.g: How many persons ...? who should be How many people .....?

2) Subject-verb agreement, e.g: Are you understand? What does it tell you? who should do you understand? What does it tell you

3) Preposition

4) to infintive, e.g: I want you observe ..... I should want you to observe

5) Perfect, e.g Capital: His car at 08.0 should have finished washed his car at 08.00

It can be seen that the minor errors that occur in the example above are a description that a language learner including an English teacher himself must have alertness to small things such as use (s / -es) for verbs followed by singular subject, plural / singular noun, subject-verb agreement, prepostion: at, on, in, etc, gerund vs infinitive, capital (perfect), Auxiliary Verb and so on. Small mistakes in English grammar affect the meaning or meaning of a word or sentence.

\section{Understanding}

It deals with giving and receiving responses, comments, or answers to statements or questions from an interaction or communication. A person's understanding of the statement or question in oral communication depends on the background of the recipient's knowledge, the message is clear or not. Understanding in responding to oral communication can also be seen from the expressions used or facial expressions displayed.

Regarding the results of research on comprehension, the level of understanding of English teachers can be seen when they are teaching in class or when they interact with students. For example, when students ask in Indonesian, English teachers rarely respond in English. Of course this contains a question mark for everyone because as an English teacher, he must respond to the student's question in English even though the teacher himself translates it later. This is because one's understanding of English can be seen when he speaks English not another language.

It is evident that from several explanations of each component of speaking skills it appears that speaking of non native English teacher as in Bengkulu, Indonesia is still weak. We realize that it is impossible for non-native speaker English teachers to be $100 \%$ like native English teachers (Gurkan \& Yuksel, 2012). Furthermore, Todd \& Pujanapunya (2008), Tang (1997) stated that English language teachers from native languages of the language are generally superior and accepted and even influence the language teaching policy.

\section{B. Factors Affecting the Speaking Skills of English Teachers of Junior High Schools and Senior High Schools in Bengkulu City Coastal School}

There are two factors that can affect one's English speaking skills, internal factors and external factors. These internal factors are factors that come from the person, such as feeling afraid of 
being wrong, anxious, not self-confident. This is in line with Gurkan \& Yuksel's (2012) opinion that one of the main characteristics of English language teachers who are not native speakers is the uncomfortable feeling of speaking in a foreign language they are pessimistic. The emergence of these feelings is most likely caused by someone's unpreparedness in speaking English or because they do not have good skills in speaking, for example the use of grammar that is still weak, lack of vocabulary, incorrect pronunciation, wrong interpretation of context according to context,. These difficulties are common difficulties often faced by non-native speakers or not native speakers of the language. So, actually, even if it is not like native speakers, but at least as a learner or instructor of English must approach the way or style of speaking of native speakers of the language, in this case English.

While the external factors commonly associated with English speaking skills are external factors that affect a person's skills when speaking English, for example environmental factors where the language learner is. An environment that supports or demands that someone learn a language will make it easier for him to master the language. For example, you are sent to England for 6 months; of course the environment that you live in is an environment that requires you to speak English. Conversely compared to the place where you came from, English might be rarely used or even never. But, because of environmental demands, you inevitably have to adapt to the local people who ask you to communicate in English. Because the environment in which you are located also determines your success in learning foreign languages.

Regarding this research, the internal factors found were factors of the English teacher himself who felt that when the English teacher spoke in full in English, students were deemed not to understand the English instruction or material given. This internal factor is certainly speculative because there is something called the "repetition" in the teaching and learning process. Instructions given by English teachers are usually repetitive and students are believed to be able to understand the instructions or instructions when the teacher is consistent with what is instructed. For example, Open your book page 10!, The instruction is often heard by students and they can guess the intent of the command / instruction. So, the reason students find it difficult to understand English-language instruction needs to be questioned.

English language material is sometimes difficult to understand, when it must be delivered in English. What needs to be a teacher's attention is that students must have strategies in learning languages, including English. Therefore, to facilitate them in understanding the material, the teacher must convey ways or strategies in learning English, for example the teacher delivered the technique of reading "scanning and skimming" techniques guessing the meaning of a word (guessing), how to multiply word vocabulary, and etc. In addition, the teacher must believe in abilities, and encourage them to remain enthusiastic in learning, provide varied learning techniques and so on

\section{CONCLUSIONS AND RECOMMENDATIONS}

From the results of the above, it can be concluded that the English teacher's speaking skills in the coastal school of Bengkulu city are at a moderate level. Fluency in speaking is the main problem faced by these teachers. In addition, grammar also becomes an obstacle for them. While the identified factors that can influence the English teacher's speaking skills are the internal factors of English teachers themselves who often use Indonesian language when teaching rather than English itself with the reason that children will easily understand the message or subject matter when compared to English. In addition to these internal factors, 
curriculum changes that are considered as external factors are also a reason for English teachers not to speak English in class with the latest curriculum consideration, namely the 2013 Curriculum requires active students not teachers.

Responding to the results of the temporary research, it is recommended to conduct further studies on the data that has been obtained. In addition, there is a need for more English language training for English teachers at the coastal school. The need for conferences or workshops to be distinguished about the role of teachers in the implementation of the 2013 curriculum or KTSP curriculum so that the emergence of a uniform understanding of the role of the teacher in the classroom.

\section{ACKNOWLEDGEMENT}

A thank you to the University of Bengkulu LPPM who has funded this research through the 2017 Guidance Research Grant with the Letter of Agreement: 1667 / UN30.15 / LT / 2017.

\section{REFERENCES}

Brown, H.D. Language Assessment: Priciples and Classroom Practice. Washington: Pearson Longman .2009.

Damayanti, I.dkk. Profil dan Kompetensi Guru Bahasa Inggris Tingkat SMA Kota Bengkulu. Laporan Penelitian Dosen Muda. Universitas Bengkulu, Desember 2014

Kamil, AB. The Effect of Teaching Methods and Learning Motivations on Students' Speaking Skill.Judika (Jurnal Pendikan UNSIKA). 2017 Mar 13;5(1).

Kurniawan, I. dkk. Analysis Pemetaan Keterampilan Berbicara Bahasa Inggris Siswa di Sekolah Daerah Pesisir Kota Bengkulu. Laporan Hibah Penelitian Pembinaan UNIB. Universitas Bengkulu, 2016

Kurniawan, I. Student's Speaking Skill and Class Participation. Prosiding pada International Seminar on Language and Literature Education 1.FKIP Universitas Bengkulu. 2015. p.209-2015.

Nation, I.S.P and Newton, J. Teaching ESL/EFL Listening and Speaking. New York: Routledge. 2009

Nunan, D. Second language teaching and learning. Boston: Heinle \& Heinle. 1999

Richard-Amato, P.A. Making it happen: Interaction in the second language classroom: from theory to Practice. White Plain, N.Y: Longman. 1996

Talley, Paul C \& and Hu-Ling, Tu. Implicit and Explicit Teaching English Speaking in the EFL Classroom. International Journal of Humanities and Social Science. 2014.Vol 4. No.6 Appril 2014. Pp 38-42. 
Voller, P. Does the teacher have a role in autonomous language learning? In P. Bearson \& P.Voller (Eds). Autonomy and Independence in Language Learning (pp: 145-167). New York: Cambridge University Press. 1997 